\title{
Integrated Application of Urea and Sawdust Ash: Effect on Soil Chemical Properties, Plant Nutrients and Sorghum Performance
}

\author{
Abdulraheem Mukhtar Iderawumi ${ }^{1}$; Ojeniyi Steven Olusola ${ }^{2}$; Charles, Eneminyene \\ Friday $^{3}$ \\ ${ }^{1}$ Department of Agricultural Education, Emmanuel Alayande College of Education, Oyo. Lanlate Campus, \\ P.M.B 001, Lanlate, Oyo State, Nigeria \\ ${ }^{2}$ Department of Crop, Soil and Pest Management, Federal University of Technology, Akure \\ ${ }^{3}$ Nigeria Institutes for Oil Palm Research, Benin City, Edo State, Nigeria
}

\begin{abstract}
Field experiment was carried out in Lanlate in rainforest zone of Southwest, Nigeria to study relative effects of combined use of Sawdust ash (SDA) and Urea (U) on soil chemical properties, nutrient status, growth and yield of sorghum (Sorghum bicolor (L.) Moench). The soil in the experimental site was low in nitrogen and phosphorus. The treatments were replicated three times on sorghum plant, there were six treatments; the control (no SDA, no urea), $240 \mathrm{~kg} / \mathrm{haU}, 4.5 \mathrm{t} / \mathrm{haSDA}+60 \mathrm{~kg} / \mathrm{haU}, 3.0 \mathrm{t} / \mathrm{haSDA}+120 \mathrm{~kg} / \mathrm{haU}, 1.5 \mathrm{t} / \mathrm{haSDA}+180 \mathrm{~kg} / \mathrm{haU}$ and 6.Ot/haSDA. Combined use of SDA and urea fertilizer increased the N,P,K,Ca and Mg content of the soil. However, urea fertilizer reduced soil $\mathrm{pH}$ relative to control. Therefore, urea fertilizer increased soil acidity. The combined use of reduced levels of ash and urea fertilizer increased growth and yield of sorghum. The sawdust ash (SDA) and co-application of reduced levels of ash and urea increased leaf $N, K, C a$ and Mg status while urea alone gave highest leaf $P$. Urea alone at $240 \mathrm{~kg} / \mathrm{ha}$ ( or $82 \mathrm{kgN} / \mathrm{ha}$ ) and $180 \mathrm{~kg} / \mathrm{haU}(111 \mathrm{kgN} / \mathrm{ha})+1.5 \mathrm{t} / \mathrm{ha}$ increased grain yield by 59 and $101 \%$ respectively. This work found out that SDA could be combined with urea to maximize grain yield of sorghum at $1.5 \mathrm{t} / \mathrm{haSDA}+180 \mathrm{~kg} / \mathrm{ha}$ urea. This approach reduces need for urea and attendant reduction in soil $\mathrm{pH}$ due to the use of fertilizer. It was also found that SDA alone or combined with urea increased significantly growth of sorghum as indicated by plant height, number of leaves and stem girth. The SDA component ensured more availability of $\mathrm{K}, \mathrm{Ca}$ and $\mathrm{Mg}$ not directly supplied by urea.
\end{abstract}

Keywords: nutrients, plant, sawdust ash, soil, sorghum, urea

\section{Introduction}

Sorghum (Sorghum bicolor (L.) Moench) accounts for $43 \%$ of all major food staples in sub-sahara Africa with respect to animal and human consumption. Nigeria produces about 6.4 million tonnes annually on about 6 million hectares of land, mainly in the savanna zone. With the potential average yield of $2.5 \mathrm{t} / \mathrm{ha}$ grains, the current national average is less than $50 \%$ being 500 to $800 \mathrm{~kg} / \mathrm{ha}$. Low soil fertility is a major factor limiting the crop yield. Agbede et al (2009) attributed lower yield of sorghum to lower soil organic matter, total $\mathrm{N}$ and available $\mathrm{P}$ on an alfisol in Owo, South West Nigeria.

There is need to step up studies into use of locally sourced organic and agricultural waste in maintaining soil fertility and yield of sorghum which is mainly grown on low fertility soils in the savanna ecology of Nigeria. Also the integrated use of organic and inorganic fertilizer should be employed to reduce need for the latter the price most farmers cannot afford.

Early studies carried out in northern Nigeria indicated that high yield of sorghum could be sustained with application of animal manure whose effect is attributable to the $\mathrm{N}$ and $\mathrm{P}$ content. In a recent study in South West Nigeria, poultry manure in combination with tillage increased dry matter and grain yield of sorghum by 33.1 and $39.5 \%$ of respectively in comparison with tillage only. Sorghum responded to soil fertility and organic manuring (Agbede et al, 2009).

The sawdust is an easily available cheap organic waste which is abound at over 2000 sawmilling plants all over Nigeria. The dust contains nutrients such as $\mathrm{P}, \mathrm{K}, \mathrm{Ca}, \mathrm{Mg}, \mathrm{Cu}, \mathrm{Zn}, \mathrm{Mn}$ and $\mathrm{Fe}$ (Adebowale). The piles of Sawdust are incinerated to pure ash. Because of the acidic nature of soil in Southern Nigeria the sawdust ash has the potential of being used to control soil acidity and supply nutrients to crop. (Owolabi et al, 2003). SDA increased Yield of Cowpea, Okra, Tomato and Uptake of P,K,Ca and Mg. Also, SDA contained $1.16 \% \mathrm{~N}, 0.04 \% \mathrm{P}, 2.8 \% \mathrm{~K}, \mathrm{Mg}$ $0.07 \%$ and $\mathrm{Ca}$ 0.35\%. (Owolabi, et al. 2003).

Plant derived ash is an agricultural and domestic waste which has been proved to be an effective source of nutrients for crops. It is a liming and fertilizer material. It also improved soil physical condition (Nyobe, 1998: AduDapaah, et al, 1994: Ojeniyi et al 2002: Ojeniyi and Adejobi, 2002: Smith et al, 2001), Araki, 1993). While ash has been tried on crops, its effect on performance of sorghum and its integrated use with inorganic fertilizers is not known to have been studied. In the study with tomato, Ewulo, et al (2009) found that combined application of $1.5 \mathrm{t} / \mathrm{ha}$ sawdust ash (SDA) and 180kg/ha urea increased fruit yield by $67 \%$ at Akure Southwest Nigeria. 
The objective of this work is to study effect of combined application of urea and sawdust ash on soil nutrient, nutrients content and performance of sorghum in the rainforest ecology.

\section{Materials And Method}

Experiment was conducted at Emmanuel Alayande College of Education, Oyo, Lanlate Campus, (EACOED) Teaching and Research Farm, Lanlate, Southwest Nigeria. Lanlate lies between latitude $7^{0} 30^{\circ} \mathrm{N}$ and Longitude $3^{0} 52$ $\mathrm{E}$ in the tropical rainforest belt. There are two rainy seasons; one from April to July (early season) and the other from mid-August to November (late season). Annual average minimum and maximum temperatures are $24.80^{\circ} \mathrm{C}$ and $28.10^{\circ} \mathrm{C}$ respectively. The mean relative humidity is about $75 \%$.

The treatments were namely; The Control (no urea, no SDA), $240 \mathrm{kgha}^{-1}$ Urea alone, $4.5 \mathrm{tha}^{-1} \mathrm{SDA}+60 \mathrm{kgha}^{-1}$ urea, 3 tha $^{-1} \mathrm{SDA}+120 \mathrm{kgha}^{-1}$ urea, 1.5 tha $^{-1} \mathrm{SDA}+180 \mathrm{kgha}^{-1}$ Urea, 6 tha ${ }^{-1}$ ash alone.

Treatments were replicated three times on manually cleared land using Randomized Complete Block Design (RCBD). Each of the 18 plots was $3 \mathrm{~m}$ by $6 \mathrm{~m}$ in size and seeds were planted at $0.60 \mathrm{~m} \mathrm{X} 0.90 \mathrm{~m}$. Ash and urea treatments were applied on soil surface three weeks after planting in ring form. Weeding was done.

Plant growth and yield parameters taken at 3, 6, 9 and 12 weeks after treatments (WAT) included plant height, stem girth, number of leaves, number of branches, and grain weight. At termination of experiment 14 weeks after treatment, root weight, leaf weight and total fresh matter weight were taken.

\section{Soil Chemical Analysis}

Surface $(0-15 \mathrm{~cm})$ soil samples were taken close to matured plant 12 weeks after treatment application using steel auger. Samples were bulked for each site, air-dried and $2 \mathrm{~mm}$ sieved for analysis (Tel and Hagarty, 1984). Total $\mathrm{N}$ by Kjedahl method, P by Bray-1 extraction followed by molybdenum blue colorimetry and $\mathrm{K}, \mathrm{Ca}$ and $\mathrm{Mg}$ by ammonium acetate extraction were determined. The exchangeable $\mathrm{K}$ was evaluated using flame photometer and $\mathrm{Ca}$ and $\mathrm{Mg}$ by EDTA titration. Soil $\mathrm{pH}$ in water was determined using $\mathrm{pH}$ meter in 1: 2 soil water ratio medium. Organic matter was determined using Walkley Black dicromate method.

\section{Plant and Sawdust Analysis}

Leaf samples collected at 10 weeks after treatment application in each plot were oven dried at $70^{\circ} \mathrm{C}$ for 24hours. Ground samples were analysed for $\mathrm{N}$ using micro Kjeldahl digestion method. Ground samples were digested using nitric - perchloric acid mixture for determination of $\mathrm{P}, \mathrm{K}, \mathrm{Ca}$ and $\mathrm{Mg}$. The $\mathrm{P}$ was determined using molybdenum blue colorimetry, $\mathrm{K}$ by flame photometer, and $\mathrm{Ca}$ and $\mathrm{Mg}$ by EDTA titration.

Sawdust ash was analysed as described for leaf.

\section{Statistical Analysis}

Data were analysed using Analysis of Variance (ANOVA) to determine the effects of treatments on the parameters measured. Duncan Multiple Range Test was used to compare the treatment means.

\section{Results And Discussion}

Analysis of the test soil gave the value for $\mathrm{pH}$ (water) to be $6.4, \mathrm{OM}=4.7 \%$, total $\mathrm{N}=0.14 \%$, available $\mathrm{P}=$ $6.2 \mathrm{mg} / \mathrm{kg}$, exchangeable $\mathrm{K}=0.12 \mathrm{cmol} / \mathrm{kg}, \mathrm{Ca}=1.5 \mathrm{cmol} / \mathrm{kg}$ and $\mathrm{Mg}=1.0 \mathrm{cmol} / \mathrm{kg}$. The soil is deficient in $\mathrm{N}, \mathrm{P}$ and $\mathrm{Ca}$. There is need for application of organic and inorganic fertilizers for crops grown on it.

Table 1 contains data on soil analysis after the experiment. Treatment had no significant effect on soil $\mathrm{pH}$. The sole sawdust ash (SDA) at 6.0t/ha gave highest value of exchangeable Mg. Urea, SDA and their integrated applications increased soil OM, available P, K, Ca and Mg relative to the control. Addition of SDA to Urea increased availability of $\mathrm{OM}, \mathrm{N}, \mathrm{P}, \mathrm{K}$ and $\mathrm{Ca}$ in soil. This observation is consistent with those of Ojeniyi et al (2002) and Ojeniyi and Adejobi (2002).

Data on nutrients composition of Sorghum are shown in Table 2. Application of urea and SDA alone or combined increased tissue $\mathrm{N}$ significantly. The urea $(\mathrm{U})$ and $1.5 \mathrm{t} / \mathrm{ha} \mathrm{SDA}+180 \mathrm{~kg} / \mathrm{ha} \mathrm{U}$ had highest tissue $\mathrm{N}$ and the latter had the highest value. Relative to control, effect of treatments on tissue $\mathrm{N}$ was significant $(\mathrm{P}>0.05)$. The treatments did not increased tissue P. Addition of urea to SDA and SDA alone increased tissue $\mathrm{K}, \mathrm{Ca}$ and $\mathrm{Mg}$ significantly relative to control and urea alone. The observation affirms ash as source of cations and liming material. The increases in uptake of $\mathrm{N}, \mathrm{K}$ and $\mathrm{Ca}$ are consistent with relatively high content of the nutrients in SDA. According to Owolabi et al (2003), SDA had $1.16 \% \mathrm{~N}, 2.8 \% \mathrm{~K}$ and $0.35 \% \mathrm{Ca}$.

Data on growth and yield parameters of sorghum as influenced by urea and SDA are shown in Table 3 . The $1.5 \mathrm{t} / \mathrm{ha} \mathrm{SDA}+180 \mathrm{~kg} / \mathrm{ha} \mathrm{U}$ and $240 \mathrm{~kg} / \mathrm{ha} \mathrm{U}$ respectively gave highest grain yield. This is consistent with the findings that the two treatments respectively had highest leaf $\mathrm{N}$ concentrations. It is thus indicated that availability of $\mathrm{N}$ most dictated yield of sorghum. Addition of SDA to urea increased plant height, stem girth. The 1.5t/ha SDA $+180 \mathrm{~kg} / \mathrm{ha} U$ most consistently increased growth and yield parameters as indicated by plant height, number of leaves, stem girth and grain yield. 


\section{Conclusion}

It is concluded that performance of sorghum and nutrients availability can be significantly increased by combining reduced levels of urea and sawdust ash (SDA). Combination of 1.5t/ha SDA $+180 \mathrm{~kg} / \mathrm{ha}$ Urea maximized uptake of $\mathrm{N}$, and yield of sorghum. Additions of SDA to urea increased soil OM, N, P, K, Ca, tissue K and Mg. The use of SDA reduced need for inorganic fertilizers in sorghum cultivation.

Other advantages of integrated plant nutrition are itemized in the review by Ojeniyi (2012) and the work reported by Ojeniyi et al (2012).

Table 1: Effect of Urea (U) and Sawdust Ash Manure (SDA) on Soil Nutrient Content at 12 weeks after Application

\begin{tabular}{|c|c|c|c|c|c|c|c|}
\hline Treatment & soil pH & $\overline{O M(\%)}$ & $\mathbf{N}(\%)$ & $\mathrm{P}(\mathrm{mg} / \mathrm{kg})$ & $\mathrm{K}(\mathrm{Cmol} / \mathrm{kg})$ & $\mathrm{Ca}(\mathrm{Cmol} / \mathrm{kg})$ & $\mathrm{Mg}(\mathrm{Cmol} / \mathrm{kg})$ \\
\hline Control & $7.54 \mathrm{a}$ & $0.54 \mathrm{a}$ & $0.14 \mathrm{a}$ & $4.7 \mathrm{a}$ & $0.25 \mathrm{c}$ & $0.20 \mathrm{a}$ & $1.20 \mathrm{~b}$ \\
\hline $240 \mathrm{~kg} / \mathrm{haU}$ & $7.25 \mathrm{a}$ & $0.66 \mathrm{~b}$ & $0.41 \mathrm{~b}$ & $6.8 \mathrm{c}$ & $0.30 \mathrm{c}$ & $0.30 \mathrm{a}$ & $0.90 \mathrm{~b}$ \\
\hline $\begin{array}{l}4.5 \mathrm{t} / \mathrm{ha} \mathrm{SDA} \\
+60 \mathrm{~kg} / \mathrm{ha} \mathrm{U}\end{array}$ & $7.01 \mathrm{a}$ & $1.33 \mathrm{c}$ & $0.71 \mathrm{~d}$ & $7.2 \mathrm{c}$ & $0.42 b$ & $0.70 \mathrm{~b}$ & $0.90 \mathrm{~b}$ \\
\hline 3.0t/ha SDA & $7.57 \mathrm{a}$ & $1.49 \mathrm{c}$ & $0.78 \mathrm{~d}$ & $8.1 \mathrm{~b}$ & $0.82 \mathrm{a}$ & $0.70 \mathrm{c}$ & $1.00 \mathrm{~b}$ \\
\hline $\begin{array}{l}+120 \mathrm{k} / \mathrm{ha} \mathrm{U} \\
1.5 \mathrm{t} / \mathrm{ha} \mathrm{SDA} \\
+180 \mathrm{~kg} / \mathrm{ha} \mathrm{U}\end{array}$ & $7.22 \mathrm{a}$ & $1.20 \mathrm{c}$ & $0.41 \mathrm{~b}$ & $9.8 \mathrm{~b}$ & $0.32 \mathrm{c}$ & $0.50 \mathrm{~d}$ & $1.00 \mathrm{~b}$ \\
\hline 6.0t/ha SDA & $7.26 \mathrm{a}$ & $1.44 \mathrm{c}$ & $0.16 \mathrm{a}$ & $12.2 \mathrm{a}$ & $0.47 \mathrm{~b}$ & $0.40 \mathrm{~d}$ & $1.50 \mathrm{a}$ \\
\hline
\end{tabular}

Means followed by the same letter within each column are not significantly different $(P=0.05)$ as indicated by Duncan's Multiple Range Test.

Table 2: Effect of Sawdust Ash Manure (SDA) and Urea (U) on Leaf Nutrients Content of Sorghum at 12 weeks after Application

\begin{tabular}{|c|c|c|c|c|c|}
\hline Treatment & N\% & P\% & $\mathrm{K} \%$ & Ca\% & Mg\% \\
\hline Control & $0.80 \mathrm{a}$ & $0.30 \mathrm{a}$ & $0.20 \mathrm{a}$ & $1.2 \mathrm{a}$ & $0.36 \mathrm{a}$ \\
\hline $240 \mathrm{~kg} / \mathrm{haU}$ & $1.82 \mathrm{~b}$ & $0.30 \mathrm{a}$ & $0.20 \mathrm{a}$ & $1.2 \mathrm{a}$ & $0.40 \mathrm{a}$ \\
\hline $\begin{array}{l}\text { 4.5t/ha SDA } \\
+60 \mathrm{~kg} / \mathrm{ha} \mathrm{U}\end{array}$ & $1.40 \mathrm{~b}$ & $0.30 \mathrm{a}$ & $1.3 b$ & $9.8 \mathrm{~b}$ & $0.50 \mathrm{~b}$ \\
\hline $\begin{array}{l}3.0 \mathrm{t} / \mathrm{ha} \mathrm{SDA} \\
+120 \mathrm{k} / \mathrm{ha} \mathrm{U}\end{array}$ & $1.54 \mathrm{~b}$ & $0.25 b$ & $1.2 \mathrm{~b}$ & $11.0 \mathrm{~b}$ & $0.57 \mathrm{~b}$ \\
\hline $\begin{array}{l}\text { 1.5t } / \mathrm{ha} \mathrm{SDA} \\
+180 \mathrm{~kg} / \mathrm{ha} \mathrm{U}\end{array}$ & $3.2 \mathrm{cb}$ & $0.28 \mathrm{a}$ & $1.0 \mathrm{~b}$ & $11.2 \mathrm{~b}$ & $0.54 \mathrm{~b}$ \\
\hline 6.0t/ha SDA & $1.68 \mathrm{a}$ & $0.22 \mathrm{~b}$ & $1.7 \mathrm{c}$ & $10.8 \mathrm{~b}$ & $0.58 \mathrm{a}$ \\
\hline
\end{tabular}


Table 3: Effect of Sawdust Ash Manure (SDA) and Urea (U) on Growth parameters and Yield of Sorghum

\begin{tabular}{|c|c|c|c|c|c|}
\hline Treatment & $\begin{array}{l}\text { Mean } \\
\text { Plant } \\
\text { height }\end{array}$ & $\begin{array}{l}\text { Mean } \\
\text { Number } \\
\text { of leaves }\end{array}$ & $\begin{array}{l}\text { Mean } \\
\text { Stem } \\
\text { girth }\end{array}$ & $\begin{array}{l}\text { Mean } \\
\text { Dry Matter } \\
\text { yield }\end{array}$ & $\begin{array}{l}\text { Mean } \\
\text { Grain } \\
\text { yield }\end{array}$ \\
\hline Control & $60.23 b$ & $8.56 \mathrm{a}$ & $31.75 b$ & $2.21 \mathrm{~b}$ & $53.67 \mathrm{bc}$ \\
\hline $240 \mathrm{~kg} / \mathrm{haU}$ & $59.38 b$ & $8.03 \mathrm{~b}$ & $30.94 b$ & $2.20 \mathrm{~b}$ & $85.33 \mathrm{ab}$ \\
\hline $\begin{array}{l}4.5 \mathrm{t} / \mathrm{ha} \mathrm{SDA} \\
+60 \mathrm{~kg} / \mathrm{ha} \mathrm{U}\end{array}$ & $71.50 \mathrm{a}$ & $8.89 a$ & $39.98 \mathrm{ab}$ & $1.71 b$ & $50.67 \mathrm{bc}$ \\
\hline $\begin{array}{l}3.0 \mathrm{t} / \mathrm{ha} \mathrm{SDA} \\
+120 \mathrm{k} / \mathrm{ha} \mathrm{U}\end{array}$ & $64.87 \mathrm{ab}$ & $8.33 \mathrm{ab}$ & $35.79 \mathrm{ab}$ & $3.42 \mathrm{a}$ & $52.00 \mathrm{c}$ \\
\hline $\begin{array}{l}1.5 \mathrm{t} / \mathrm{ha} \mathrm{SDA} \\
+180 \mathrm{~kg} / \mathrm{ha} \mathrm{U}\end{array}$ & $68.15 \mathrm{ab}$ & $8.74 \mathrm{ab}$ & $39.41 \mathrm{ab}$ & $2.01 b$ & $107.67 \mathrm{a}$ \\
\hline 6.0t/ha SDA & $71.24 \mathrm{ab}$ & $8.68 \mathrm{ab}$ & $47.64 \mathrm{ab}$ & $2.67 \mathrm{ab}$ & $39.33 c$ \\
\hline
\end{tabular}

Means followed by the same letter within each column are not significantly different $(P=0.05)$ as indicated by Duncan's Multiple Range Test.

\section{References}

[1] Adebowale, E. A. 1985: Non-conventional feed sources in Nigeria. IFOJ 2/3,181-189.

[2] Adu-Dapaah, H. K., Cobbinah, J. and Asare, E.O. 1994: Effect of cocoa pod ash on the growth of maize. Journal of Agricultural Science $120,31-33$

[3] Agbede, T.M., Ojeniyi S.O. and Adekayode, F.O. 2009: Effect of Tillage on Soil Properties and Yield of Sorghum in Southwest Nigeria. Nigerian Journal of Soil Science 19(2), $1-10$.

[4] Araki, S.I993: Effect of soil organic matter and soil fertility of the Chitemene slash and burn practice used in northern Zambia, In Mulongoy, K. and Merck, K. (Editors) Soil organic matter dynamics and sustainability of tropical agriculture Wiley Sayce, UK. 367-378.

[5] Ewulo, B.S., Babadele, O.O. and Ojeniyi S.O. 2009: Sawdust ash and Urea Effects on Soil and Plant Nutrient Contents and Yield of Tomato. American-Eurasian Journal of Sustainable Agriculture. 3(1), 88 - 92

[6] Nyobe, T. 1998: Physical properties of an ultisol under traditional and improved management practices. Ph.D. Thesis, University of Ibadan, $327 \mathrm{pp}$.

[7] Ojeniyi, S.O. and Adejobi, K.B. 2002: Effects of ash and goat dung manure on leaf Nutrient composition, growth and yield of amaranthus. The Nigeria Agricultural Journal 33, 46-57

[8] Ojeniyi, S. O; Oso, O. P. and Arowotolu, A. A. 2002: Response of vegetables to wood ash Fertilizer. Proceeding $35^{\text {th }}$ Annual Conference of Agricultural Society of Nigeria, UNAAB Abeokuta. p 39-43

[9] Ojeniyi, S.O. 2012: Advances in Integrated Nutrients Management for Crop Production in Nigeria. Nigeria Journal of Technological Research 7,39-43

[10] Ojeniyi, S.O., Adejoro, S.A., Ikotun, O. and Amusan, O. 2012: Soil and Plant Nutrient Composition and Yield of Cassava as Influenced by Integrated Application of NPK Fertilizer and Poultry Manure. New York Science Journal 5(9), 62 - 68

[11] Owolabi, O., A. Adeyeye, B.T. Oladejo and S.O. Ojeniyi, 2003: Effect of wood ash on soil fertility and crop yield in Southwest Nigeria. Nig. J. Soil Sci., 13: 55-60.

[12] Owolabi, O., S.O Ojeniyi, A.O Amodu and K.Hassan, 2003: Response of Cowpea, Okra and Tomato to Sawdust Ash Manre. Moor Journal of Agricultural Research 4(2), 179-182

[13] Smith, M. A. K; Ojeniyi S.O. and Oladejo, B.T. 2001: Influence of wood ash based soil amendments on weed occurrence and diversity in a humid tropical environment. Journal of Sustainable Agriculture and Environment. 3, 270-275.

[14] Tel, D.A. and M. Hagarty 1984: Soil and Plant Analysis. IITA Ibadan/University of Guelph, Ontario, Canada, pp: 277.

\section{About Authors}

Abdulraheem, Mukhtar Iderawumi is the Farm Manager, Department of Agricultural Education, Emmanuel Alayande College of Education, Oyo, Lanlate Campus, Lanlate, Oyo State, Nigeria; Professor Steven Olusola Ojeniyi is a Professor of Soil Fertility at the Federal University of Technology, Akure, Nigeria and the current Editor-in-Chief of Nigerian Journal of Soil Science while Charles, Eneminyene Friday is currently an Assistant Chief Agricultural Superintendent at the Nigeria Institutes for Oil Palm Research, Benin City, Edo State, Nigeria 